\begin{tabular}{|lll|}
\hline \multicolumn{3}{|c|}{ OTOBUANG } \\
\hline Volume 6 & Nomor 2, Desember 2018 & Halaman 269-282 \\
\hline
\end{tabular}

\title{
PENGGUNAAN MODEL PEMBELAJARAN LANGSUNG SEBAGAI STRATEGI MENGAJAR MUSIKALISASI PUISI \\ (The Use of Direct Learning Models as a Strategy to Teach Musical Poetry)
}

\author{
Sakila \\ SMP Negeri 2 Singkawang \\ Jalan Pahlawan, Kota Singkawang, Indonesia \\ Pos-el: sakilaspd@yahoo.co.id
}

(Diterima: 15 Oktober 2018; Direvisi: 5 November 2018; Disetujui: 19 November 2018)

\begin{abstract}
Writing this scientific article examines the use of direct learning models as a musical learning strategy for poetry. The purpose of this paper is to describe the use of direct learning models as a musical learning strategy for poetry. The data collection process is carried out using the literature study method. The collected data is selected and sorted according to the study topic. Then the preparation of the paper is based on data that has been prepared logically and systematically. Data analysis techniques are descriptive argumentative. The formulation of the problem contained in this paper is how to use direct learning methods as a musical learning strategy for poetry. Based on data analysis, it was concluded that using direct learning models can improve students' ability in learning poetry musicization. Based on this, it is recommended that teachers can apply direct learning models to improve students' ability in learning poetry musicilization.
\end{abstract}

Keywords: model, direct teaching, musical poetry

\begin{abstract}
Abstrak
Penulisan artikel ilmiah ini mengkaji tentang penggunaan model pembelajaran langsung sebagai strategi pembelajaran musikalisasi puisi. Tujuan penulisan ini adalah untuk mendeskripsikan penggunaan model pembelajaran langsung sebagai strategi pembelajaran musikalisasi puisi. Proses pengumpulan data dilakukan dengan metode studi kepustakaan. Data yang terkumpul diseleksi dan diurutkan sesuai dengan topik kajian. Kemudian dilakukan penyusunan karya tulis berdasarkan data yang telah dipersiapkan secara logis dan sistematis. Teknik analisis data bersifat deskriptif-argumentatif. Rumusan masalah yang terdapat pada tulisan ini adalah bagaimanakah penggunaan metode pembelajaran langsung sebagai strategi pembelajaran musikalisasi puisi. Berdasarkan analisis data disimpulkan bahwa dengan menggunakan model pembelajaran langsung dapat meningkatkan kemampuan siswa dalam pembelajaran musikalisasi puisi. Berdasarkan hal tersebut, disarankan agar guru dapat menerapkan model pembelajaran langsung untuk meningkatkan kemampuan siswa dalam pembelajaran musikalisasi puisi.
\end{abstract}

Kata-kata kunci: model, pengajaran langsung, musikalisasi puisi

\section{PENDAHULUAN}

Pada Pembukaan Undang-Undang Dasar Negara Republik Indonesia tahun 1945 dinyatakan bahwa salah satu tujuan pembentukan Negara Kesatuan Republik Indonesia adalah untuk mencerdaskan kehidupan bangsa. Usaha untuk mencerdaskan kehidupan bangsa ini tidak akan berhasil kalau tidak didukung oleh guru yang profesional. Hal ini menunjukkan bahwa peranan guru sangat penting dalam proses pendidikan. Sebagai seorang pendidik dituntut untuk selalu kreatif menggunakan model dan metode dalam pelaksanaan pembelajaran. Putranta, (2018:3) mengemukakan bahwa model pembelajaran adalah suatu perencanaan atau suatu pola yang digunakan sebagai pedoman dalam merencanakan kegiatan pembelajaran di kelas. Model tersebut merupakan pola umum perilaku pembelajaran untuk mencapai kompetensi atau tujuan pembelajaran yang diharapkan. Model pembelajaran adalah pola interaksi peserta didik dengan guru di dalam kelas yang menyangkut pendekatan, strategi, metode, teknik pembelajaran yang 
diterapkan dalam pelaksanaan kegiatan pembelajaran (Putranta, 2018:3).

Selain itu, berbicara mengenai metode Rofa'ah (2016:69) mengemukakan bahwa metode adalah cara yang di dalam fungsinya merupakan alat untuk mencapai suatu tujuan. Makin baik metode yang dipakai, makin efektif pula pencapaian tujuan yang akan dicapai. Lebih lanjut menurutnya bahwa secara umum metode atau metodik berarti ilmu tentang jalan yang dilalui untuk mengajar kepada peserta didik supaya dapat tercapai tujuan belajar mengajar. Dalam kegiatan pembelajaran seorang guru tidak harus terpaku dalam menggunakan berbagai metode (variasi metode) agar proses pembelajaran berjalan tidak membosankan, tetapi bagaimana memikat perhatian anak didik (Rofa'ah, 2016:69). Metode pembelajaran merupakan suatu cara atau strategi yang dilakukan oleh seorang guru agar terjadi proses pembelajaran pada diri siswa untuk mencapai tujuan yang diharapkan (Rofa'ah, 2016:70).

Berdasarkan pendapat tersebut di atas, maka dalam proses pembelajaran seorang guru harus mampu mengembangkan metode pembelajaran yang efektif, kreatif dan menyenangkan, sebagaimana yang diisyaratkan dalam Kurikulum Tingkat Satuan Pendidikan. Salah satunya adalah menggunakan model pembelajaran langsung dalam pokok bahasan musikalisasi puisi.

Pokok bahasan musikalisasi puisi terdapat dalam silabus mata pelajaran Bahasa Indonesia tingkat SMP/MTs kelas IX semester 1 dengan standar kompetensi mengungkapkan kembali cerpen dan puisi dalam bentuk lain. Berdasarkan hal tersebut maka kompetensi dasar yang harus dikuasai siswa dan materi pokok yang diajarkan oleh guru adalah seperti tertera pada tabel 1 di bawah ini :

Tabel 1

Kompetensi Dasar dan Materi Pembelajaran

\begin{tabular}{|c|c|}
\hline $\begin{array}{c}\text { Kompetensi } \\
\text { Dasar }\end{array}$ & $\begin{array}{c}\text { Materi } \\
\text { Pembelajaran }\end{array}$ \\
\hline 6.2. Menyanyikan & Materi Pembelajaran \\
\hline
\end{tabular}

270

\begin{tabular}{|l|l|}
\hline puisi yang sudah & 1. Teks puisi \\
dimusikalisasi & 2. Unsur-unsur puisi \\
dengan & 3. Cara menemukan \\
berpedoman pada & suasana puisi \\
kesesuaian isi puisi & 4. Cara \\
dan suasana/irama & menghubungkan \\
yang dibangun. & $\begin{array}{l}\text { suasana puisi } \\
\text { dengan irama } \\
\text { musikalisasi puisi }\end{array}$ \\
& $\begin{array}{l}\text { 5. Cara menyanyikan } \\
\text { puisi yang sudah } \\
\text { dimusikalisasi }\end{array}$ \\
\hline
\end{tabular}

Permasahan yang sering terjadi di kelas pada saat pembelajaran musikalisasi puisi adalah kesulitan siswa dalam mengungkapkan isi puisi. Salah satu penyebabnya adalah kemampuan guru yang belum memadai dalam hal pengetahuan maupun cara mengajarkannya. Selain itu, minat dan kemampuan siswa menjadi salah satu faktor yang berpengaruh. Kurangnya minat disebabkan karena faktor pemilihan model dan metode pembelajaran yang dipilih oleh guru. Hal ini sebagaimana dikemukakan Susanto (2013:267) bahwa pemilihan metode pembelajaran diperlukan oleh guru pada saat merancang proses kegiatan belajar mengajar. Karena ketepatan pemilihan metode pembelajaran akan berdampak terhadap efektifitas pencapaian kompetensi pembelajaran yang telah ditetapkan.

Berdasarkan hal tersebut di atas, maka penulis beranggapan bahwa agar siswa mampu melaksanakan pembelajaran musikalisasi puisi maka diperlukan model pembelajaran yang cocok untuk dilaksanakan. Berkaitan dengan rendahnya kemampuan siswa dalam pembelajaran musikalisasi tidak selayaknya dibiarkan begitu saja. Akan tetapi, perlu kiranya dilakukan sebuah upaya untuk menindaklanjutinya dalam rangka perbaikan, salah satunya alternatifnya adalah dengan menerapkan suatu pendekatan pembelajaran yang lebih inovatif, maka penulis tertarik untuk melakukan penulisan artikel ilmiah mengenai penggunaan model pembelajaran 
langsung dalam pembelajaran musikalisasi puisi.

Berdasarkan latar belakang masalah yang telah disebutkan di atas, maka masalah dalam pembahasan tulisan ini adalah bagaimana penggunaan model pembelajaran langsung dalam meningkatkan kemampuan siswa dalam musikalisasi puisi di kelas IX.

Sesuai dengan latar belakang masalah yang telah disebutkan di atas, maka tujuan penulisan tinjauan ilmiah ini adalah untuk mendeskripsikan langkah-langkah penggunaan model pembelajaran langsung dalam meningkatkan kemampuan siswa dalam musikalisasi puisi pada mata pelajaran Bahasa Indonesia di jenjang SMP/MTs.

Manfaat yang diharapkan dari tulisan ini adalah sebagai berikut: Secara teoritis. Melalui teori-teori yang digunakan, penulis memperoleh tambahan pengetahuan, serta pengalaman tentang penggunaan model pembelajaran langsung dalam meningkatkan kemampuan siswa dalam pembelajaran musikalisasi puisi. Secara Praktis. Bagi siswa, (a) Siswa memperoleh pengalaman dari proses belajarnya, sehingga mampu meningkatkan motivasi dalam belajarnya. (2) Memberikan pengalaman yang sesungguhnya kepada siswa untuk belajar sesuai konteks, yang menantang kreatifitas dan menyenangkan. Bagi guru, (a) Menambah pengetahuan guru dalam mengelola pembelajaran Bahasa Indonesia berdasarkan model pembelajaran langsung dalam meningkatkan kemampuan siswa dalam pembelajaran musikalisasi puisi. (b) Menambah pengalaman bagi guru dalam mengajarkan musikalisasi puisi, sehingga dengan pengalaman ini guru akan makin sadar untuk terus berinovasi dalam mengelola pembelajaran agar lebih bermakna bagi siswa serta evaluasi hasil belajar siswa.

\section{LANDASAN TEORI}

Hakikat Model dan metode pembelajaran
Konsep model pembelajaran menurut Trianto dalam Afandi, dkk (2013:15) menyebutkan bahwa model pembelajaran adalah suatu perencanaan atau pola yang digunakan sebagai pedoman dalam merencanakan pembelajaran di kelas atau pembelajaran tutorial. Model pembelajaran mengacu pada pendekatan pembelajaran yang akan digunakan, termasuk di dalamnya tujuan-tujuan pengajaran, tahap-tahap dalam kegiatan pembelajaran, lingkungan pembelajaran, dan pengelolaan kelas. Sedangkan metode pembelajaran menurut Djamarah, SB. dalam Afandi, dkk (2013:16) "suatu cara yang dipergunakan untuk mencapai tujuan yang telah ditetapkan." Dalam kegiatan belajar mengajar, metode diperlukan oleh guru agar penggunaanya bervariasi sesuai yang ingin dicapai setelah pengajaran berakhir.

Dari pengertian tersebut di atas, maka Afandi, dkk (2013:16) mengemukakan bahwa dari konsep pembelajaran, model dan metode pembelajaran dapat didefinisikan bahwa model pembelajaran adalah prosedur atau pola sistematis yang digunakan sebagai pedoman untuk mencapai tujuan pembelajaran didalamnya terdapat strategi, teknik, metode, bahan, media dan alat penilaian pembelajaran. Sedangkan metode pembelajaran adalah cara atau tahapan yang digunakan dalam interaksi antara peserta didik dan pendidik untuk mencapai tujuan pembelajaran yang telah ditetapkan sesuai dengan materi dan mekanisme metode pembelajaran.

\section{Model Pembelajaran Langsung}

Menurut Depdiknas dalam Afandi, dkk (2013:16) pembelajaran langsung dapat didefinisikan sebagai model pembelajaran di mana guru mentransformasikan informasi atau keterampilan secara langsung kepada peserta didik, pembelajaran berorientasi pada tujuan dan distrukturkan oleh guru. Model pembelajaran langsung menurut Arends dalam Trianto (2011:29) adalah "salah satu pendekatan mengajar yang 
dirancang khusus untuk menunjang proses belajar siswa yang berkaitan dengan pengetahuan deklaratif dan pengetahuan prosedural yang terstruktur dengan baik yang dapat diajarkan dengan pola kegiatan yang bertahap, selangkah demi selangkah."

Sejalan dengan hal tersebut Widaningsih (2010:150) mengemukakan bahwa pengetahuan prosedural yaitu pengetahuan mengenai bagaimana orang melakukan sesuatu, sedangkan pengetahuan deklaratif, yaitu pengetahuan tentang sesuatu. Pembelajaran langsung tidak sama dengan metode ceramah, tetapi ceramah dan resitasi (mengecek pemahaman dengan tanya jawab) berhubungan erat dengan model pembelajaran langsung. Guru berperan sebagai penyampai informasi, dan dalam hal ini guru seyogyanya menggunakan berbagai media yang sesuai, misalnya film, tape recorder, gambar, peragaan, dan sebagainya. Adapun ciri-ciri pengajaran langsung sebagaimana pendapat Widaningsih, (2010:151) adalah sebagai berikut :

1. Adanya tujuan pembelajaran dan prosedur penilaian hasil belajar.

2. Sintaks atau pola keseluruhan dan alur kegiatan pembelajaran.

3. Sistem pengelolaan dan lingkungan belajar yang mendukung berlangsung dan berhasilnya pengajaran.

Pembelajaran langsung memiliki pola urutan kegiatan yang sistematis untuk mengetahui kegiatan-kegiatan yang harus dilakukan oleh guru atau peserta didik, agar pembelajaran langsung tersebut terlaksana dengan baik. Menurut Kardi \& Nur dalam Trianto (2011:31) fase-fase pada model pembelajaran langsung dapat dilihat pada Tabel 2 di bawah ini.

Tabel 2

Fase dan Peran Guru dalam Model Pembelajaran Langsung

\begin{tabular}{|l|l|l|}
\hline No & \multicolumn{1}{|c|}{ Fase } & \multicolumn{1}{c|}{ Peran Guru } \\
\hline 1. & $\begin{array}{l}\text { Menyampaikan } \\
\text { Tujuan } \\
\text { Pembelajaran dan }\end{array}$ & $\begin{array}{l}\text { Menjelaskan } \\
\text { Tujuan, Materi } \\
\text { Prasyarat, }\end{array}$ \\
\hline
\end{tabular}

\begin{tabular}{|l|l|l|}
\hline & $\begin{array}{l}\text { mempersiapkan } \\
\text { siswa }\end{array}$ & $\begin{array}{l}\text { memotivasi siswa, } \\
\text { dan } \\
\text { mempersiapkan } \\
\text { siswa }\end{array}$ \\
\hline 2. & $\begin{array}{l}\text { Mendemonstrasi } \\
\text { kan Pengetahuan } \\
\text { dan Keterampilan }\end{array}$ & $\begin{array}{l}\text { Mendemonstrasik } \\
\text { an keterampilan } \\
\text { atau menyajikan } \\
\text { informasi tahap } \\
\text { demi tahap }\end{array}$ \\
\hline 3. & $\begin{array}{l}\text { Membimbing } \\
\text { Pelatihan }\end{array}$ & $\begin{array}{l}\text { Guru memberi } \\
\text { latihan terbimbing }\end{array}$ \\
\hline 4. & $\begin{array}{l}\text { Mengecek } \\
\text { pemahaman dan } \\
\text { memberikan } \\
\text { umpan balik }\end{array}$ & $\begin{array}{l}\text { Mengecek } \\
\text { kemampuan siswa } \\
\text { dan memberikan } \\
\text { umpan balik }\end{array}$ \\
\hline 5. & $\begin{array}{l}\text { Memberikan } \\
\text { latihan dan } \\
\text { penerapan } \\
\text { konsep }\end{array}$ & $\begin{array}{l}\text { Mempersiapkan } \\
\text { latihan untuk } \\
\text { siswa dengan } \\
\text { menerapkan } \\
\text { konsep yang } \\
\text { dipelajari pada } \\
\text { kehidupan sehari- } \\
\text { hari }\end{array}$ \\
\hline
\end{tabular}

Sumber :Kardi \& Nur (Trianto 2011:31)

Kelebihan dan Kelemahan Model Pembelajaran Langsung menurut Widaningsih (2010:153) adalah sebagai berikut: kelebihan model pembelajaran langsung, (1) Relatif banyak materi yang bisa tersampaikan. (2) Untuk hal-hal yang sifatnya prosedural, model ini akan relatif mudah diikuti. Sedangkan Kekurangan / kelemahan model pembelajaran langsung adalah jika terlalu dominan pada ceramah, maka siswa merasa cepat bosan. Pembelajaran langsung akan terlaksana dengan baik apabila guru mempersiapkan materi yang akan disampaikan dengan baik pula dan sistematis, sehingga tidak membuat peserta didik cepat bosan dengan materi yang dipelajari.

\section{Musikalisasi Puisi}

Menurut Danardana (2013:56) musikalisasi puisi adalah kolaborasi apresiasi seni antara musik, puisi dan pentas. Dengan musikalisasi puisi, seseorang tidak hanya mendapat kesempatan mengapresiasi puisi dan musik tapi juga mendapatkan kesempatan mengekspresikan apresiasi seninya itu di depan umum. Selanjutnya 
menurut Ari KPIN (2008:9) musikalisasi puisi dapat didefinisikan sebagai sarana mengomunikasikan puisi kepada apresin melalui persembahan musik (nada, irama, lagu dan nyanyian). Senada dengan itu, Arsie (1996:16) menegaskan bahwa musikalisasi puisi adalah satu bentuk ekspresi sastra, puisi dengan melibatkan beberapa unsur seni, seperti irama, bunyi (musik), gerak (tari). Selanjutnya menurut Tjahjono (2011:167) dalam musikalisasi boleh saja terdapat kegiatan pembacaan puisi sebab tidak semua baris atau frase dalam puisi bisa dimusikalisasikan; membaca puisi dengan alat musik juga merupakan kegiatan musikalisasi puisi. Hal ini senada dengan Sucipto (2015:148) musikalisasi puisi merupakan cara mengubah puisi ke dalam bentuk musik atau melagukan puisi.

Berdasarkan pendapat tersebut di atas, dapat ditarik kesimpulannya, bahwa musikalisasi puisi adalah sebuah sarana untuk mengkolaborasikan serta mengapresiasikan sebuah atau beberapa puisi yang dilakukan dengan melalui pengubahan syair serta pembacaan puisi serta memadukan unsur seni, seperti irama, bunyi (musik) juga unsur gerak (tari), dan disertai alat musik.

\section{METODE}

Dalam penulisan ini, penulis menggunakan metode deskriptif, yaitu metode berdasarkan fakta yang ada atau fenomena yang secara empiris hidup pada pengguna-penggunanya. Data-data yang dipergunakan dalam penyusunan karya tulis ini berasal dari berbagai literatur kepustakaan yang berkaitan dengan permasalahan yang dibahas. Beberapa jenis referensi utama yang digunakan adalah buku pelajaran Bahasa Indonesia, jurnal ilmiah edisi cetak maupun edisi online, dan artikel ilmiah yang bersumber dari internet. Jenis data yang diperoleh variatif, bersifat kualitatif maupun kuantitatif. Metode penulisan bersifat studi pustaka. Informasi didapatkan dari berbagai literatur dan disusun berdasarkan hasil studi dari informasi yang diperoleh. Penulisan diupayakan saling terkait antar satu sama lain dan sesuai dengan topik yang dibahas. Metode pengumpulan data yang digunakan dalam penelitian adalah studi pustaka. Menurut Nazir (1998:112) bahwa studi kepustakaan merupakan langkah yang penting dimana setelah seorang peneliti menetapkan topik penelitian, langkah selanjutnya adalah melakukan kajian yang berkaitan dengan teori yang berkaitan dengan topik penelitian. Dalam pencarian teori, peneliti akan mengumpulkan informasi sebanyak-banyaknya dari kepustakaan yang berhubungan. Sumber-sumber kepustakaan dapat diperoleh dari : buku, jurnal, majalah, hasil-hasil penelitian (tesis dan disertasi), dan sumber-sumber lainnya yang sesuai (internet, koran dll). Data yang terkumpul diseleksi dan diurutkan sesuai dengan topik kajian. Kemudian dilakukan penyusunan karya tulis berdasarkan data yang telah dipersiapkan secara logis dan sistematis. Teknik analisis data bersifat deskriptif argumentatif. Simpulan didapatkan setelah merujuk kembali pada rumusan masalah, tujuan penulisan, serta pembahasan. Simpulan yang ditarik mempresentasikan pokok bahasan karya tulis, serta didukung dengan saran praktis sebagai rekomendasi selanjutnya.

\section{PEMBAHASAN}

\section{Alasan Pemilihan Strategi Pemecahan Masalah}

Pada dasarnya metode apapun yang dipilih oleh guru harus memperhatikan prinsip-prinsip dalam kegiatan belajar mengajar seperti berpusat kepada peserta didik, learning by doing, mengembangkan sikap sosial, mengembangkan keingintahuan serta imajinasi serta mengembangkan kreativitas dan keterampilan dalam memecahkan masalah (Mariyaningsih, 2018:14-15). 
Ada beberapa indikator ciri-ciri metode pembelajaran yang efektif menurut pendapat Mariyaningsih, (2018:11-12) sebagai berikut: (1) Meningkatkan pemahaman siswa terhadap materi pelajaran. (2) Membuat siswa tertantang. (3) Membangun rasa ingin tahu siswa. (4) Meningkatkan keaktifan siswa. (5) Merangsang daya kreativitas siswa. (6) Mudah dilaksanakan oleh guru.

Beberapa situasi yang memungkinkan model pembelajaran langsung menurut Depdiknas dalam Afandi, dkk. (2013:19-20) sebagai berikut :

1) Ketika guru ingin mengenalkan suatu bidang pembelajaran yang baru dan memberikan garis besar pelajaran dengan mendefinisikan konsep-konsep kunci dan menunjukan keterkaitan di antara konsep-konsep tersebut.

2) Ketika guru ingin mengajari peserta didik suatu keterampilan atau prosedur yang memiliki struktur yang jelas dan pasti.

3) Ketika guru ingin memastikan bahwa peserta didik telah menguasai keterampilan-keterampilan dasar yang diperlukan dalam kegiatan-kegiatan yang berpusat pada peserta didik misalnya penyelesaian masalah (problem solving).

4) Ketika guru ingin menunjukan sikap dan pendekatan pendekatan intelektual (misalnya menunjukan bahwa suatu argumen harus didukung oleh buktibukti, atau bahwa suatu argumen harus didukung oleh bukti-bukti, atau bahwa suatu penjelajahan ide tidak selalu berujung pada jawaban yang logis)

5) Ketika subyek pembelajaran yang akan diajarkan cocok untuk dipresentasikan dengan pola penjelasan, pemodelan, pertanyaan, dan penerapan.
6) Ketika guru ingin menumbuhkan keterkaitan peserta didik akan suatu topik.

7) Ketika guru harus menunjukan teknik atau prosedur-prosedur tertentu sebelum peserta didik melakukan suatu kegiatan praktik.

8) Ketika guru ingin menyampaikan kerangka parameterparameter untuk memandu peserta didik dalam melakukan kegiatan pembelajaran kelompok atau independen.

9) Ketika para peserta didik menghadapi kesulitan yang sama yang dapat diatasi dengan penjelasan yang sangat terstruktur.

10) Ketika lingkungan mengajar tidak sesuai dengan strategi yang berpusat pada peserta didik atau ketika guru tidak memiliki waktu untuk melakukan pendekatan yang berpusat pada peserta didik.

Berdasarkan hal tersebut di atas, maka dapat disimpulkan bahwa alasan pemilihan model pembelajaran langsung, adalah karena model pembelajaran ini sangat efektif untuk mengukur pencapaian kompetensi dasar yang ada dalam kurikulum, keahlian dalam memahami suatu materi dan konsep menurut pemikirannya sendiri.

Selain itu, model pembelajaran langsung dilaksanakan dengan harapan meningkatkan kreatifitas siswa dan memudahkan guru dalam melaksanakan proses pembelajaran dan pada akhirnya dapat meningkatkan kualitas pembelajaran. Meningkatkan kualitas pembelajaran dalam arti bahwa pemahaman siswa meningkat dan kinerja guru dalam pembelajaran juga meningkat.

\section{Implementasi Strategi Pemecahan}

Masalah

Pelaksanaan Model Pembelajaran Langsung 
Menurut Sukarti (2016:60) dalam model pengajaran langsung, pada umumnya guru merencanakan kegiatan belajar mengajar secara terstruktur dan ketat. Pada awal pembelajaran, guru merupakan pemberi informasi dan pendemonstrasi yang aktif dan mengharapkan siswa menjadi pendengar aktif dan baik. Keberhasilan pengajaran langsung memerlukan lingkungan yang baik untuk presentasi dan demonstrasi, yakni ruangan yang tenang dengan penerangan yang cukup, termasuk alat pandang dengar yang sesuai.

Langkah-langkah pengajaran langsung meliputi tahapan-tahapan: a) menyampaikan tujuan; b) menyiapkan siswa; c) presentasi; d) mencapai kejelasan; e) demonstrasi; f) mencapai pemahaman dan penguasaan; g) berlatih; h) memberikan latihan terbimbing; i) mengecek pemahaman dan memberikan umpan balik; dan j) memberikan kesempatan latihan mandiri (Sukarti, 2016:60).

Dalam Model pengajaran langsung salah satu cirinya adalah diterapkannya strategi modeling, yaitu strategi yang dikembangkan berdasarkan prinsip bahwa seseorang dapat belajar melalui pengamatan perilaku orang lain. Langkah-langkah modeling menurut Bandura (1986) dalam (Trianto, 2013: 53) terdiri dari fase atensi, fase retensi, fase produksi, dan fase motivasi. Dalam pembelajaran musikalisasi puisi, implementasi model pembelajaran langsung perlu dimodifikasi sedemikian rupa. Modifikasi ini diperlukan agar fase-fase kegiatan dapat dilaksanakan dengan baik sesuai dengan karakter pembelajaran musikalisasi puisi. Perubahan bisa dilakukan sejauh tidak menyimpang dari tata urutan yang disarankan dalam model pembelajaran langsung.

Menurut At-Taubany dan Suseno (2017:217) pengajaran langsung yang bertumpu pada prinsip-prinsip psikologi perilaku dan teori belajar sosial, telah dirancang secara khusus untuk menunjang proses belajar siswa yang berkaitan dengan pengetahuan prosedural dan deklaratif yang terstruktur dengan baik, yang dapat diajarkan dengan pola kegiatan bertahap, selangkah demi selangkah. Lebih lanjut menurut Lefudin (2017:43-44) pada tingkah laku mengajar dalam model pembelajaran langsung terdapat lima fase yang sangat penting. Guru mengawali pelajaran dengan pekerjaan tentang tujuan dan latar belakang pembelajaran, serta mempersiapkan siswa untuk menerima penjelasan guru. Fase persiapan dan motivasi ini kemudian diikuti oleh presentasi materi ajar yang diajarkan atau demontrasi tentang keterampilan tertentu. Pelajaran ini termasuk juga pemberian kesempatan kepada siswa untuk melakukan pelatihan dan pemberian umpan balik terhadap keberhasilan siswa.

Pada fase pelatihan dan pemberian umpan balik tertentu, guru perlu selalu mencoba memberikan kesempatan kepada siswa untuk menerapkan pengetahuan atau keterampilan yang dipelajari ke dlam situasi kehidupan nyata. Rangkuman kelima fase tersebut dapat dilihat pada tabel 3 di bawah ini :

Tabel 3

Sintaks Model Pembelajaran Langsung

\begin{tabular}{|l|l|}
\hline \multicolumn{1}{|c|}{ Fase-Fase } & \multicolumn{1}{c|}{ Perilaku Guru } \\
\hline $\begin{array}{l}\text { FASE 1 } \\
\text { Menyampaikan tujuan dan mempersiapkan } \\
\text { siswa }\end{array}$ & $\begin{array}{l}\text { Guru menyampaikan tujuan, informasi informasi } \\
\text { latar belakang pelajaran, pentingnya pelajaran } \\
\text { ini, mempersiapkan siswa untuk belajar }\end{array}$ \\
\hline $\begin{array}{l}\text { FASE 2 } \\
\text { Mendemonstrasikan pengetahuan atau } \\
\text { keterampilan }\end{array}$ & $\begin{array}{l}\text { Guru mendemonstrasikan keterampilan yang } \\
\text { benar, atau menyajikan informasi tahap demi } \\
\text { tahap. }\end{array}$ \\
\hline
\end{tabular}


Totobuang, Vol. 6, No. 2, Desember 2018: 269-282

\begin{tabular}{|l|l|}
\hline $\begin{array}{l}\text { FASE 3 } \\
\text { Membimbing pelatihan }\end{array}$ & $\begin{array}{l}\text { Guru merencanakan dan memberi bimbingan } \\
\text { pelatihan awal }\end{array}$ \\
\hline $\begin{array}{l}\text { FASE 4 } \\
\text { Mengecek pemahaman dan memberikan } \\
\text { umpan balik }\end{array}$ & $\begin{array}{l}\text { Mengecek apakah siswa telah berhasil } \\
\text { melakukan tugas dengan baik, memberi umpan } \\
\text { balik. }\end{array}$ \\
\hline $\begin{array}{l}\text { FASE 5 } \\
\text { Memberikan kesempatan untuk pelatihan } \\
\text { lanjutan dan penerapan }\end{array}$ & $\begin{array}{l}\text { Guru mempersiapkan kesempatan melakukan } \\
\text { pelatihan lanjutan, dengan perhatian khusus } \\
\text { pada penerapan kepada situasi lebih kompleks } \\
\text { dan kehidupan sehari-hari }\end{array}$ \\
\hline
\end{tabular}

Sumber: Lefudin. (2017:44)

Adapun penjelasan 5 Fase Model Pembelajaran Langsung adalah sebagai berikut :

\section{Fase 1 Menyampaikan Tujuan dan Mempersiapkan Siswa}

a. Menyampaikan tujuan

Pada fase ini guru menyampaikan tujuan pembelajaran musikalisasi puisi dengan memberikan apersepsi pembelajaran dan tanya jawab tentang materi musikalisasi puisi. Selanjutnya ditindaklanjuti dengan memberikan motivasi kepada siswa dan diakhiri dengan Tanya jawab. Para siswa perlu mengetahui dengan jelas, mengapa mereka berpatisipasi dalam suatu pelajaran tertentu, dan mereka perlu mengetahui apa yang harus mereka lakukan setelah selesai berperan serta dalam pelajaran itu (Kardi dan Nur, 2000: 27).

b. Menyiapkan siswa

Tujuan pembelajaran tahap awal ini adalah untuk membangun kesiapan siswa dalam pembelajaran musikalisasi puisi. Kegiatan ini bertujuan untuk menarik perhatian siswa, memusatkan perhatian siswa pada pokok pembicaraan, dan mengingatkan kembali pada hasil belajar yang telah dimilikinya, yang relevan dengan pokok pembicaraan yang akan dipelajari, tujuan ini dapat dicapai dengan jalan mengulang pokok-pokok pembicaraan pelajaran yang lalu, atau memberikan sejumlah pertanyaan kepada siswa (Kardi dan Nur, 2000:29). Menyiapkan siswa yaitu memusatkan perhatian siswa pada materi yang akan kita ajarkan, membantu siswa melihat relevansi pelajaran, serta memotivasi siswa berperan aktif selama proses pembelajaran berlangsung.

2. Fase 2 Mendemonstrasikan Pengetahuan dan Keterampilan.

Memulai kegiatan musikalisasi puisi guru mengajak siswa untuk mencermati contoh/model musikalisasi puisi. Contoh tersebut diatas melalui tayangan dari video selanjutnya ditampilkan oleh siswa dan guru. Dengan melihat langsung contoh tersebut siswa dapat langsung bertanya dan guru berusaha mengintensifkan pemahaman siswa. Menurut Kardi dan Nur (2000:31-33) kunci untuk berhasil ialah mempresentasikan informasi sejelas mungkin dan mengikuti langkah-langkah demonstrasi yang efektif adalah sebagai berikut:

a. Mencapai kejelasan

Kemampuan guru untuk memberikan informasi yang jelas dan spesifik kepada siswa, mempunyai dampak yang positif terhadap proses belajar siswa. Sementara itu, pada guru pemula dan belum berpengalaman ditemukan banyak penjelasan yang kabur dan membingungkan. Hal ini pada umumnya terjadi pada saat guru tidak menguasai sepenuhnya isi pokok 
bahasan yang diajarkannya, dan tidak meguasai teknik komunikasi yang baik.

\section{b. Melakukan demonstrasi}

Agar dapat mendemonstrasikan suatu konsep atau keterampilan dengan berhasil, guru perlu sepenuhnya menguasai konsep atau keterampilan yang akan di demonstrasikan, dan berlatih melakukan demonstrasi untuk menguasai komponen-komponennya.

\section{Fase 3 Membimbing pelatihan}

Pada fase ini siswa disuruh membentuk kelompok musikalisasi puisi. Tiap kelompok terdiri dari beberapa siswa yang heterogen sesuai jumlah siswa. Selanjutnya siswa disuruh mencari dan memilih puisi yang diinginkannya. Siswa dalam kemompok mendiskusikan beberapa aspek sebelum melaksanakan kegiatan musikalisasi puisi. Selanjutnya siswa merencanakan latihan awal musikalisasi puisi. Hal ini sebagaimana pendapat Kardi dan Nur (2000:35-36) prinsip-prinsip yang dapat digunakan sebagai acuan bagi guru dalam menerapkan dan melakukan pelatihan diantaranya:

- Tugasi siswa melakukan latihan singkat dan bermakna

- Berikan pelatihan sampai benar-benar menguasai konsep atau keterampilan yang dipelajari.

- Hati-hati terhadap kelebihan dan kelemahan latihan berkelanjutan dan latihan terdistribusi.

- Perhatikan tahap-tahap awal pelatihan.

\section{Fase 4 Mengecek Pemahaman dan} Memberikan Umpan Balik.

Kegiatan ini merupakan aspek penting dalam pembelajaran langsung, karena tanpa mengetahui hasilnya, latihan tidak banyak manfaatnya bagi siswa, dalam kenyataannya, tugas paling penting bagi guru dalam menggunakan model pembelajaran langsung adalah memberi siswa umpan balik bermakna dan pengetahuan tentang hasil latihannya
(Kardi dan Nur, 2000: 37). Fase ini ditandai dengan pertanyaan-pertanyaan yang diberikan oleh guru kepada siswa dan siswa memberikan tanggapan berupa jawaban yang menurut mereka benar. Selanjutnya, guru merespon jawaban yang diberikan siswa tersebut. Guru dapat menggunakan berbagai cara untuk memberikan umpan balik kepada siswa, misalnya umpan balik secara lisan, tes, dan komentar tertulis (Kardi dan Nur, 2000: 37). Umpan balik sebaiknya diberikan seusai pelatihan dan sesuai dengan tingkat perkembangan siswa, sehingga siswa dapat mengetahui dan memperbaiki kesalahannya dalam menjawab latihan.

\section{Fase 5 Memberikan Kesempatan untuk} Pelatihan Lanjutan dan Penerapan.

Menurut Kardi dan Nur (2000:42-43) kebanyakan latihan mandiri yang diberikan kepada siswa sebagai fase akhir pelajaran pembelajaran langsung adalah pekerjaan rumah, ada tiga panduan umum untuk latihan-latihan mandiri yang diberikan sebagai Pekerjaan Rumah (PR) diantaranya:

- Tugas rumah yang diberikan bukan merupakan kelanjutan dari proses pembelajaran, tetapi merupakan kelanjutan pelatihan untuk pembelajaran berikutnya.

- Guru semestinya menginformasikan kepada orang tua siswa tentang tingkat keterlibatan mereka yang diharapkan.

- Guru seharusnya memberikan umpan balik tentang Pekerjaan Rumah (PR) tersebut.

Sebagai tindak lanjut pembelajaran musikalisasi pada fase kelima ini dan dalam upaya memotivasi siswa dapat dilanjutkan dengan menugaskan siswa dengan pembentukan beberapa kelompok musikalisasi puisi kelas, mengadakan acara perlombaan musikalisasi puisi antar kelas, atau pementasan musikalisasi puisi pada kegitan yang lebih besar. 
Menurut Bruce dan Weil dalam Depdiknas (2010: 25), tahapan model pembelajaran langsung adalah sebagai berikut :

1) Orientasi. Sebelum menyajikan dan menjelaskan materi baru, akan sangat menolong peserta didik jika guru memberikan kerangka pelajaran dan orientasi terhadap materi yang akan disampaikan. Bentuk-bentuk orientasi dapat berupa :

a) Kegiatan pendahuluan untuk mengetahui pengetahuan yang relevan dengan pengetahuan yang telah dimiliki peserta didik.

b) Mendiskusikan atau menginformasikan tujuan pelajaran

c) Memberikan penjelasan atau arahan mengenai kegiatan yang akan dilakukan selama pembelajaran

d) Menginformasikan kerangka pelajaran.

2) Presentasi. Pada fase ini guru dapat menyajikan materi pelajaran baik berupa konsep-konsep maupun keterampilan. Penyajian materi dapat berupa : a) Penyajian materi dalam langkah-langkah kecil sehingga materi dapat dikuasai peserta didik dalam waktu relatif pendek. b) Pemberian contoh-contoh konsep. c) Pemodelan atau peragaan keterampilan dengan cara demonstrasi atau penjelasan langkah-langkah kerja terhadap tugas. d) Menjelaskan ulang hal-hal yang sulit.

3) Latihan Terstruktur. Pada fase ini guru memandu peserta didik untuk melakukan latihan-latihan. Peran guru yang penting dalam fase ini adalah memberikan umpan balik terhadap respon peserta didik dan memberikan penguatan terhadap respon peserta didik yang benar dan mengkoreksi tanggapan peserta didik yang salah.

4) Latihan Terbimbing. Pada fase ini guru memberikan kesempatan kepada peserta didik untuk berlatih konsep atau keterampilan. Latihan terbimbing ini baik juga digunakan oleh guru untuk menilai kemampuan peserta didik untuk melakukan tugasnya. Pada fase ini peran guru adalah memonitor dan memberikan bimbingan jika diperlukan.

5) Latihan Mandiri. Pada fase ini peserta didik melakukan kegiatan latihan secara mandiri. Fase ini dapat dilalui peserta didik jika telah menguasai tahap-tahap pengerjaan tugas.

\section{Penilaian Pencapaian Kompetensi Dasar}

a) Teknik : unjuk kerja

b) Bentuk instrumen :-

c) Soal/instrumen

- Carilah sebuah puisi bertema keindahan alam!

- Tentukan suasana puisi tersebut!

- Tampilkan musikalisasi puisi di depan kelas!

Tabel 4

Rubrik Musikalisasi Puisi

\begin{tabular}{|l|l|l|l|l|l|}
\hline No & Aspek yang Dinilai & \multicolumn{3}{|l|}{ Skor } \\
\hline 1 & $\begin{array}{l}\text { Kesesuaian antara isi } \\
\text { puisi dengan } \\
\text { irama/ suasana yang } \\
\text { dibangun pada } \\
\text { musikalisasi }\end{array}$ & 1 & 2 & 3 & 4 \\
\hline 2 & Kekompakan & 1 & 2 & 3 & 4 \\
\hline 3 & Kreativitas & 1 & 2 & 3 & 4 \\
\hline & Total Skor Maksimal & \multicolumn{4}{|l|}{12} \\
\hline
\end{tabular}

Nilai Akhir = $\begin{gathered}\text { Perolehan Skor } \\ \text {------------------- }\end{gathered}$

\section{Hasil yang Dicapai}

Hasil yang dicapai dari pelaksanaan model pembelajaran langsung dalam pembelajaran musikalisasi adalah sebagai berikut :

a) Siswa terlihat aktif, kreatif dan senang dalam proses pembelajaran. Hal ini dapat terjadi karena model pembelajaran langsung dirancang dengan seksama dan mendetail mulai pada proses perencanaan dan pelaksanaannya. 
b) Penguasaan materi lebih mendalam karena siswa mendapat bimbingan dari guru secara intensif.

c) Pengajaran dilakukan selangkah demi selangkah untuk menumbuhkan sikap percaya diri, berani, kesungguhan, keberanian serta tanggung jawab terhadap sekolah, keluarga dan masyarakat.

d) Mengajarkan kepada siswa untuk mampu menerapkan apa yang telah dipelajari, sehingga menghilangkan kebiasaan menghapal materi pelajaran.

\section{Kendala-Kendala yang Dihadapi \\ Faktor-faktor yang mempengaruhi pembelajaran apresiasi puisi}

Menurut Sukarti (2016:55) kurangnya motivasi pembelajaran apresiasi puisi kemungkinan disebabkan oleh adanya beberapa faktor antara lain : (1) lemahnya metode pembelajaran yang diterapkan; (2) kurang adanya sarana pendukung kegiatan pembelajaran sastra; (3) lemahnya kualitas kegiatan pembelajaran sastra; dan (4) kurangnya kompetensi guru dalam melaksanakan pembelajaran sastra. Kondisi pembelajaran musikalisasi puisi selama ini berlangsung monoton dan ala kadarnya. Dalam kegiatan ini, siswa cenderung pasif dan tidak bisa terlibat secara intens dalam proses pembelajaran. Tentu saja hal ini menyebabkan tidak maksimalnya hasil pembelajaran. Menurut Sukarti (2016:55) ada beberapa kesulitan yang dialami siswa dalam melakukan kegiatan musikalisasi puisi, terutama yang berkaitan dengan: a) pemilihan jenis dan judul puisi; b) penentuan irama/musik, dan c) pengaturan penampilan kelompok. Kegiatan pembelajaran yang dirancang oleh guru ternyata juga kurang mampu memotivasi dan menumbuhkan perasaan senang siswa terhadap kegiatan musikalisasi puisi tersebut. Akibat dari kurang maksimalnya pembelajaran musikalisasi puisi, hasil akhir pembelajaran ini sangat rendah. Yang lebih memprihatinkan lagi, kegiatan pembelajaran musikalisasi puisi selama ini berlangsung konvensional dan sekadarnya saja.

\section{Kelemahan dari Model pembelajaran langsung.}

Adapun kelemahan dari model pembelajaran langsung menurut Lefudin (2017:46) sebagai berikut:

a) Model pembelajaran langsung bersandar pada kemampuan siswa untuk mengasimilasikan informasi melalui kegiatan mendengarkan, mengamati, dan mencatat. Karena tidak semua siswa memiliki keterampilan dalam hal-hal tersebut, guru masih harus mengajarkannya kepada siswa,

b) Dalam model pembelajaran langsung, sulit untuk mengatasi perbedaan dalam hal kemampuan, pengetahuan awal, tingkat pembelajaran dan pemahaman, gaya belajar atau ketertarikan siswa.

c) Karena siswa hanya memiliki sedikit kesempatan untuk terlibat secara aktif, sulit bagi siswa untuk mengembangkan keterampilan social dan interpersonal mereka;

d) Karena guru memainkan peran pusat dalam model ini, kesuksesan strategi pembelajaran ini bergantung pada image guru. Jika guru tidak tampak siap, berpengetahuan, percaya diri, antusias, dan terstruktur, siswa dapat menjadi bosan, teralihkan perhatiannya, dan pembelajaran mereka akan terhambat.

e) Terdapat beberapa bukti penelitian bahwa tingkat struktur dan kendali guru yang tinggi dalam kegiatan pembelajaran, yang menjadi karakteristik model pembelajaran langsung, dapat berdampak negatif terhadap kemampuan penyelesaian masalah, kemandirian, dan keingintahuan siswa.

\section{Faktor-Faktor Pendukung}

Faktor-faktor yang mendukung pembelajaran musikalisasi puisi dengan metode langsung adalah: 
1. Minat dan komitmen siswa tinggi. Siswa memiliki minat dan komitmen yang tinggi untuk melaksanakan musikalisasi puisi sehingga dapat menyelesaikan tepat waktu.

2. Pembimbingan intesif guru. Guru melakukan pembimbingan intesif pada tahap persiapan, pelaksanaan, dan akhir pada pembelajaran musikalisasi puisi. Hal ini sebagaimana dikemukakan oleh Lefudin. (2017:44) adapun kelebihan model pembelajaran langsung adalah guru mengendalikan isi materi dan urutan informasi yang diterima oleh siswa sehingga dapat mempertahankan fokus mengenai apa yang harus dicapai oleh siswa.

3. Dukungan dana dan motivasi dari orang tua siswa. Orang tua siswa mendukung pembelajaran musikalisasi pusi berupa dukungan dana, motivasi, dan sebagainya.

4. Penggunaan model pembelajaran langsung yang mempunyai kelebihan dibanding dengan model pembelajaran lainnya. Hal ini sebagaimana dikemukakan Lefudin (2017:44--46). berikut ini beberapa kelebihan dari pembelajaran langsung:

a. Dapat diterapkan secara efektif dalam kelas yang besar maupun kecil;

b. Dapat digunakan untuk menekankan poin-poin penting atau kesulitankesulitan yang mungkin dihadapi siswa sehingga hal-hal tersebut dapat diungkapkan;

c. Dapat menjadi cara yang efektif untuk mengajarkan informasi dan pengetahuan faktual yang sangat terstruktur.

d. Merupakan cara yang paling efektif untuk mengajarkan konsep dan keterampilan-keterampilan yang eksplisit kepada siswa yang berprestasi rendah.

e. Dapat menjadi cara untuk menyampaikan informasi yang banyak dalam waktu yang relative singkat yang dapat diakses secara setara oleh seluruh siswa;

f. Memungkinkan guru untuk menyampaikan ketertarikan pribadi mengenai mata pelajaran (melalui presentasi yang antusias) yang dapat merangsang ketertarikan dan antusiasme siswa;

g. Ceramah merupakan cara yang bermanfaat untuk menyampaikan informasi kepada siswa yang tidak suka membaca atau yang tidak memiliki keterampilan dalam menyusun dan menafsirkan informasi;

h. Secara umum, ceramah adalah cara yang paling memungkinkan untuk menciptakan lingkungan yang tidak mengancam dan bebas stress bagi siswa. Para siswa yang pemalu, tidak percaya diri, dan tidak memiliki pengetahuan yang cukup tidak merasa dipaksa dan berpartisipasi dan dipermalukan.

i. Model pembelajaran langsung dapat digunakan untuk membangun model pembelajaran dalam bidang studi tertentu. Guru dapat menunjukkan bagaimana suatu permasalahan dapat didekati, bagaimana informasi dianalisis, dan bagaimana suatu pengetahuan dihasilkan;

j. Pengajaran yang eksplisit membekali siswa dengan cara-cara disipliner dalam memandang dunia (dan) dengan menggunakan perspektif-perspektif alternative yang menyadarkan siswa akan keterbatasan perspektif yang inheren dalam pemikiran sehari-hari;

k. Model pembelajaran langsung yang menekankan kegiatan mendengar (misalnya ceramah) dan mengamati (misalnya demontrasi) dapat membantu siswa yang cocok belajar dengan cara-cara ini; 
1. Ceramah dapat bermanfaat untuk menyampaikan pengetahuan yang tidak tersedia secara langsung bagi siswa, termasuk contoh-contoh yang relevan dan hasil-hasil penelitian terkini;

m. Model pembelajaran langsung (terutama demontrasi) dapat memberi siswa tantangan untuk mempertimbangkan kesenjangan yang terdapat di antara teori (yang seharusnya terjadi) dan observasi (kenyataan yang mereka lihat);

\section{Alternatif Pengembangan}

Tindak lanjut penggunaan model pembelajaran langsung dalam musikalisasi puisi antara lain dengan bimbingan guru, siswa merancang sebuah kegiatan musikalisasi puisi yang lebih besar, misalnya pagelaran musikalisasi puisi antar kelas, festival musikalisasi puisi, dan sebagainya.

\section{PENUTUP}

Guru sebagai aktor utama dalam pendidikan perlu didukung dengan komponen pendidikan dalam pelaksanaan tugas-tugasnya. Salah satu komponen pendidikan tersebut adalah penguasaan yang baik terhadap strategi pembelajaran. Dengan kata lain bahwa keberhasilan pelaksanaan pendidikan amat tergantung dari penguasaan guru terhadap strategi pembelajaran. Salah satu strategi guru dalam pembelajaran musikalisasi puisi adalah penggunaan model pembelajaran langsung yang berpusat pada guru sehingga guru akan menyampaikan pembelajaran yang sangat terstruktur, mengarahkan kegiatan peserta didik dan mempertahankan fokus pada peningkatan prestasi akademik siswa. Model pembelajaran langsung mempunyai karakteristik adanya sintaks atau tahapan pembelajaran. Model pembelajaran langsung mempunyai kelebihan guru dapat mengendalikan isi materi dan urutan informasi yang diterima oleh siswa sehingga dapat mempertahankan fokus mengenai apa yang harus dicapai oleh siswa.

Model pembelajaran langsung dalam pembelajaran musikalisasi puisi dapat dikembangkan dengan fase-fase: a) Penyiapan tujuan dan persiapan siswa; b) Pendemonstrasian pengetahuan atau keterampilan; c) Pembimbingan pelatihan; d) Pengecekan pemahaman dan umpan balik; d) Pengintensifan latihan dan penampilan;serta e) Pelatihan lanjutan dan penerapan. Dengan pola kegiatan yang bertahap, penggunaan model pembelajaran langsung dalam musikalisasi puisi dapat meningkatkan kemampuan dan hasil belajar siswa dalam pembelajaran tersebut.

\section{DAFTAR PUSTAKA}

Afandi, Muhamad., Evi Chamalah, Oktarina Puspita Wardani. 2013. Model Dan Metode Pembelajaran Di Sekolah, Semarang: UNISSULA Press.

Ari KPIN. 2008. Musikalisasi Puisi. Yogyakarta: Hikayat.

Arsie, Freddy D. 1996. Proses Musikalisasi Deavies Sanggar Matahari. Jakarta: Balai Pustaka.

Danardana, Agus Sri. 2013. Pelangi Sastra Ulasan dan Model-Model Apresisasi. Pekanbaru: Palagan Pers.

Depdiknas, Direktorat Pembinaan Pendidikan dan Pelatihan. 2010. Model-Model Pembelajaran. Jakarta : Depdiknas.

Kardi, S dan Nur, M. 2000. Pengajaran Langsung. Surabaya: Pusat Sains dan Matematika Sekolah Program Pasca Sarjana UNESA.

Lefudin. 2017. Belajar dan Pembelajaran dilengkapi dengan Model Pembelajaran, Strategi Pembelajaran, Pendekatan Pembelajaran dan Metode Pembelajaran. Yogyakarta: Deepublish.

Mariyaningsih, Nining., Mistina Hidayati. 2018. Bukan kelas biasa: Teori dan Praktik Berbagai Model dan Metode Pembelajaran Menerapkan Inovasi 
Totobuang, Vol. 6, No. 2, Desember 2018: 269-282

Pembelajaran di Kelas-Kelas Inspiratif. Surakarta: CV Kekata Group.

Nazir. 1998. Metode Penelitian. Jakarta : Rineka Cipta.

Putranta, Himawan. 2018, Model Pembelajaran Kelompok Sistem Perilaku: Behavior System Group Learning Model. Tanpa Kota: Himawan Putranta.

Rofa'ah. 2016. Pentingnya Kompetensi Guru dalam Kegiatan Pembelajaran dalam Perspektif Islam. Yogyakarta: Deepublish.

Sucipto, Maya Gustina., Y. Budi Artati. 2015. Pegangan Guru Bahasa Indonesia. Klaten: PT Intan Pariwara.

Sukarti. 2016. "Pembelajaran Musikalisasi Puisi Melalui Model Pengajaran Langsung.” Bastra, Vol.3, No.1, Edisi Juni 2016. hal 53-64.
Susanto, Ahmad. 2013. Teori Belajar dan Pembelajaran di Sekolah Dasar. Jakarta: Prenadamedia group.

Tjahjono, Tengsoe. 2011. Mendaki Gunung Puisi ke arah kegiatan apresiasi. Cetakan 1. Malang: Banyu Media Publishing.

Trianto Ibnu Badar At-Taubany, Hadi Suseno. 2017. Desain Pengembangan Kurikulum 2013 di Madrasah. Depok: Kencana.

Trianto. 2011. Model-model pembelajaran inovatif berorientasi konstruktivitis. Jakarta:Prestasi Pustaka.

Trianto. 2013. Mendesain Model pembelajaran inovatifprogresif:Konsep, Landasan, dan Implementasinya pada Kurikulum Tingkat Satuan Pendidikan (KTSP). Jakarta: Kencana.

Widaningsih, Dedeh. 2010. Perencanaan Pembelajaran matematika. Bandung: Rizqi Press. 